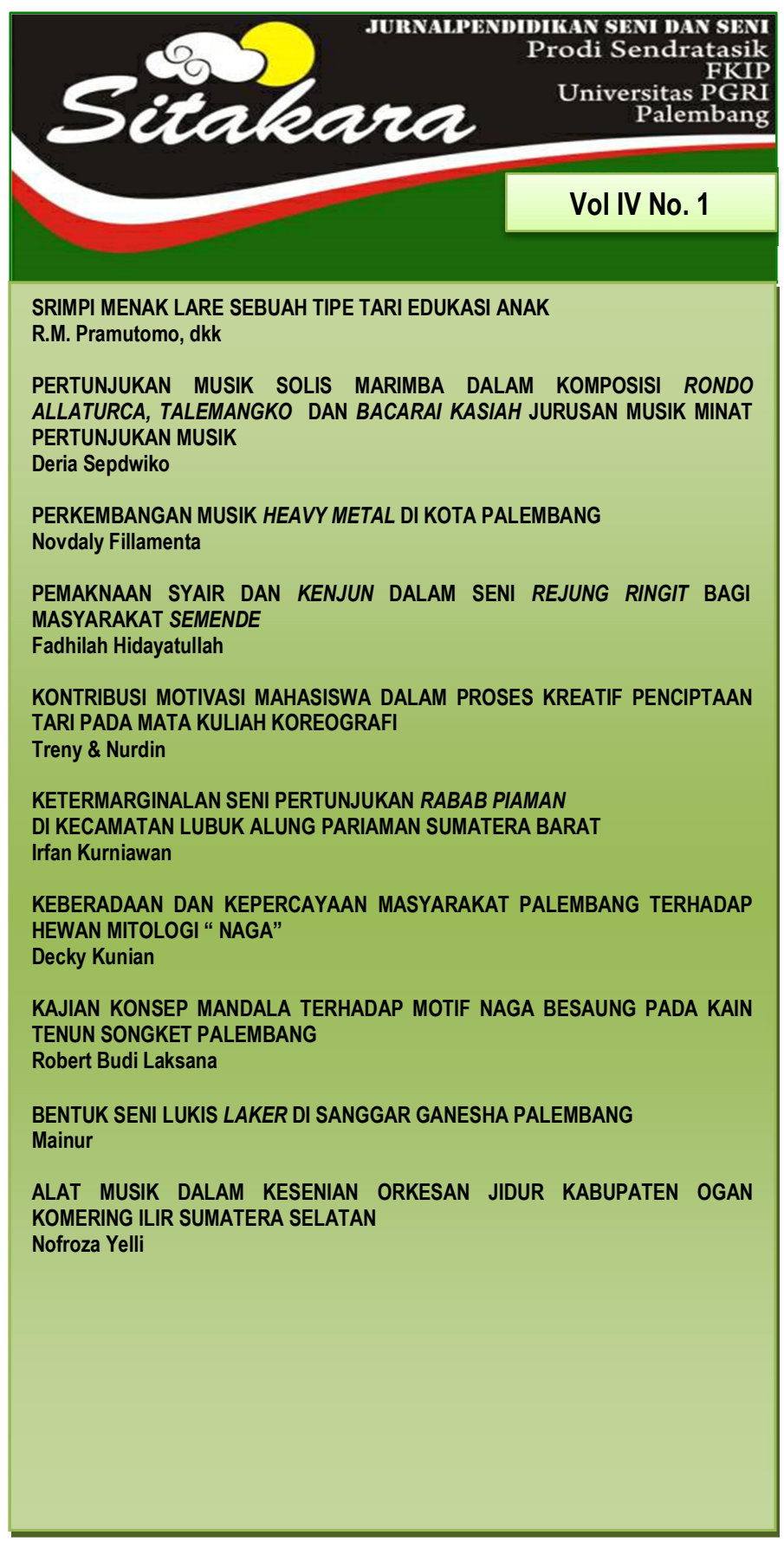




\section{DEWAN REDAKSI JURNAL "SITAKARA"}

$\begin{array}{ll}\text { 1. Penanggung Jawab } & \text { : Dra. Andina Sari, M.M } \\ \text { 2. Ketua Dewan Redaksi } & \text { : Rully Rochayati, M.Sn } \\ \text { 3. Wakil Dewan Redaksi } & \text { : Nofroza Yeli, M.Sn } \\ \text { 4. Sekretaris } & \text { : Treny Hera, S.Pd., M.Sn } \\ \text { 5. Penyunting Pelaksana } & : \text { 1. Evita Elfandari, M.Sn } \\ & \text { 2. Auzi Madona Adoma, M.Sn } \\ & \text { 3. Sherly Marita Utami, M.Pd } \\ \text { 6. Penyunting Ahli } & \text { 1. Yayan Hariyansyah, M.Sn (UIGM) } \\ & \text { 2. Desi Wardiyah, M.Pd (UPGRI) } \\ & \text { 3. Dr. Slamet, M.Hum (ISI Surakarta) } \\ & \text { 4. Hajizar, M.Sn (ISI Padang Panjang) } \\ \text { 7. Setting } & \text { 1. Drs. Marah Adiel, M.Sn } \\ & \text { 2. Mainur, S.Pd., M.Sn } \\ & \text { 3. Arfani, S.Sn., M.Pd }\end{array}$




\section{Ketentuan Penulisan Artikel Jurnal $\mathbf{S T}$ IAKA RA}

1. Naskah berbahasa Indonesia bertemakan Seni Budaya yang meliputi hasil penelitian pengajaran seni budaya, cabang seni, dan kebudayaan.

2. Naskah harus asli dan belum pernah dimuat dalam media lain. Naskah dapat berupa hasil penelitian perorangan atau kelompok.

3. Naskah ditulis dengan cara-cara yang sesuai dengan ketentuan penulisan artikel ilmiah menggunakan bahasa Indonesia yang baku, berupa ketikan, beserta soft line dalam CD-RW atau dengan mengirimkan email pada redaksi Jurnal SITAKA RA dengan alamat email: jurnalsitakarasendratasik@yahoo.com, spasi 1,5 jenis huruf Arrial Narrow ukuran 12, dengan panjang naskah antara 8-15 halaman pada kertas A4.

4. Artikel hasil penelitian memuat:

JUDUL

Nama Penulis

Abstrak

\section{A. PENDAHUluan}

B. METODE PENELITIAN

C. HASIL DAN PEMBAHASAN

D. SIMPULAN

\section{: XXX (HURUF KAPITAL)}

: (disertai jabatan dan institusi)

: (Bahasa Indonesia yang memuat 100150 kata diikuti kata kunci, dengan jenis huruf Arrial Narrow dan ukuran huruf 11 spasi tunggal serta dicetak miring)

: (Memuat latar belakang masalah, tinjauan pustaka secara ringkas, masalah penelitian dan tujuan penelitian)

5. Artikel kajian konseptual memuat:

JUDUL

Nama Penulis

Abstrak

\section{: XXX (HURUF KAPITAL)}

: (disertai jabatan dan institusi)

: (Bahasa Indonesia yang memuat 100150 kata diikuti kata kunci, dengan jenis huruf Arrial Narrow dan ukuran huruf 11 serta dicetak miring)

PENDAHULUAN
: (Memuat latar belakang masalah, tinjauan pustaka secara ringkas, 
Sub Judul

Sub Judul SIMPULAN

DAFTAR PUSTAKA masalah penelitian dan tujuan

penelitian)

: Sesuai dengan kebutuhan (tanpa numbering)

: (Berisi simpulan dan saran)

: (Berisi pustaka yang dirujuk dalam uraian naskah

6. Referensi sumber dalam teks artikel ditulis dengan menggunakan side note, contoh: (Jalalluddin, 1991:79); (Taufik, 2005;350); (Hamid dan Madjid, 2011:43). Sementara penulisan daftar pustaka disusun dengan ketentuan. Nama Pengarang. Tahun Terbit. Judul (dicetak miring). Kota Terbit: Nama Penerbit. Contoh: Koentjaraningrat. 2010. Manusia dan Kebudayaan Di Indonesia. Jakarta: Djambatan.

Daftar pustaka hanya memuat pustaka/sumber yang dirujuk dalam uraian dan disusun menurut abjad, tanpa nomor urut.

7. Naskah yang dimuat akan disunting kembali oleh redaksi tanpa mengubah isinya.

8. Naskah yang ditolak (tidak bisa dimuat) akan dikirim kembali ke penulis dengan pemberitahuan tertulis dari redaksi atau alamat email.

9. Penulis yang naskahnya dimuat akan mendapatkan 1 (satu) majalah nomor yang bersangkutan.

10. Contact Person: Treny Hera (085357344704) dan Mainur (081373165553). 


\title{
BENTUK SENI LUKIS LAKER DI SANGGAR GANESHA PALEMBANG
}

\author{
Oleh: \\ Mainur \\ (Program Studi Pendidikan Sendratasik FKIP Universitas PGRI Palembang)
}

\begin{abstract}
ABSTRAK
Lukisan laker adalah karya seni rupa murni dua dimensi yang merupakan hasil pengembangan dari seni kerajinan lak Palembang yang memiliki ciri khas tersendiri. Laker identik dengan warna kuning yang menjadi pelapis hiasan dengan sapuan cat hitam, dan keemasan. Dari beberapa referensi, diketahui nama laker diadopsi dari istilah bahasa Inggris lacquer, yaitu bahan damar yang dihasilkan oleh sejenis serangga bernama Laccifer lacca. Tumbuhan tersebut merupakan tempat bertenggernya serangga dan banyak ditemukan di Jepang, Tiongkok, dan Pegunungan Himalaya.

Metode yang digunakan adalah metode deskriptif kualitatif. Teknik pengumpulan data yang digunakan yakni teknik observasi, wawancara dan dokumentasi.
\end{abstract}

Kata Kunci : Bentuk, Lukisan Laker, Palembang

\section{A. PENDAHULUAN}

Di kota Palembang terdapat beberapa sanggar seni rupa yang mendidik pelukis dan seniman-seniman muda yang berbakat yaitu sanggar Ganesha yang beralamat di Jl. KH. Ahmad Dahlan no. 74 Kecamatan Bukit Kecil yang di ketuai oleh Bapak Harun Rosidi Kamil. Bermula dari kecintaan terhadap seni lukis membuatnya membentuk sebuah kelompok atau komunitas yang aktif membuat karya-karya seni lukis serta mengembangkan seni lukis di Palembang. Dalam membina dan mengembangkan seni lukis di sanggar ini, Bapak Harun Rosidi Kamil menciptakan karya seni lukis dengan berbagai media dan teknik.

Media yang digunakan berbeda dari lukisan pada umumnya, biasanya menggunakan berbagai warna dan berbagai jenis cat, tetapi tidak dengan seni lukis laker, lukisan ini dominan menggunakan warna hitam, merah dan kuning emas. Saat ini seni lukis laker di kota Palembang telah berkembang dengan banyaknya seniman atau perupa yang membuat karya-karya seni rupa khas seni lukis laker.

Laker berasal dari bahasa Inggris lacquer (tinner yang digunakan untuk mengawetkan kayu) lukisan ini menggunakan bahan-bahan yang hampir sama pada pembuatan kerajinan lak, tetapi proses pembuatannya berbeda dari lukisan pada umumnya serta membutuhkan waktu yang cukup lama, itu sebabnya harga lukisan ini terbilang lebih mahal dari lukisan biasanya.
Lukisan laker dari sanggar Ganesha sudah banyak dikenal dan dikoleksi oleh beberapa kolektor seni dan pejabat-pejabat di kota Palembang untuk menghiasi ruang penting seperti beberapa lukisan laker yang terpajang di ruang rapat kantor Gubernur Sumatera Selatan, di rumah dinas Wali Kota Palembang, dan beberapa kolektor yang mengoleksi seni lukis laker.

Herbert Read dalam bukunya yang berjudul The Meaning of Art (1959), menyebutkan bahwa seni merupakan usaha manusia untuk menciptakan bentuk-bentuk yang menyenangkan. Bentuk yang menyenangkan dalam arti bentuk yang dapat membingkai perasaan keindahan dan perasaan keindahan itu dapat terpuaskan apabila dapat menangkap harmoni atau satu kesatuan dari bentuk yang disajkan (Dharsono, 2007:7).

Dalam bahasa Inggris, seni dikenal dengan istilah "art".Dalam bahasa latin seni dikenal dengan istilah "ars" yang berarti keterampilan atau kemahiran. Orang Yunani mengatakan bahwa kata " art "sama dengan techne, kemudian berkembang menjadi teknik. Jadi seni identik dengan teknik, (Yuliastuti,2009:1).

Menurut Leo Tolstoy seni adalah ungkapan perasaan seniman yang disampaikan kepada orang lain agar mereka dapat merasakan apa yang dirasakannya. Dengan seni, seniman memberikan, menyalurkan, memindahkan perasaannya kepada orang lain sehingga orang itu merasakan apa yang 
dirasakan sang seniman. Lebih dari itu, orang itu pun dapat menerima perasaan seniman dengan kondisi yang sama, Sumardjo (2000:62-63).

Pengertian seni rupa lebih kepada membentuk karya dengan media yang dapat ditangkap secara visual dan dirasakan dengan perabaan. Jika dilihat dari fungsinya, seni rupa terbagi menjadi seni rupa murni dan seni rupa terapan, seni rupa murni yaitu proses penciptaan lebih menekankan pada ekspresi jiwa. Sedangkan seni rupa terapan atau applied art, lebih sering disebut sebagai kriya, yang proses pembuatannya memiliki tujuan dan fungsi tertentu.

Seni rupa merupakan salah satu kesenian yang mengacu pada bentuk visual atau sering disebut bentuk perupaan, yang merupakan susunan atau komposisi atau satu kesatuan dari unsur-unsur seni rupa. Struktur seni rupa atau penyusunan unsur rupa dalam mewujudkan bentuk pada seni rupa diperlukan hukum atau asas penyusunan, merupakan dasar dari pengamatan/pemahaman seni (Dharsono, 2007:35).

Seni lukis adalah suatu ungkapan pengalaman estetik seseorang yang dituangkan dalam bidang dua dimensi (dua matra), dengan menggunakan medium rupa, yaitu garis, warna, tekstur, shape, dan sebagainya. Medium rupa dapat dijangkau melalui berbagai macam jenis material seperti tinta, cat/pigmen tanah liat, semen dan berbagai aplikasi yang memberi kemungkinan untuk mewujudkan medium rupa, Dharsono (2004:36).

Aktifitas melukis adalah mengaplikasikan cat, pigmen, warna atau medium lain pada suatu permukaan. Cara mengaplikasikan medium tersebut umumnya dengan kuas, bisa juga dengan alat lain misalnya pisau, spons, dan kuas semprot (airbrushes).

\section{Lukisan Laker}

Kata Laker diadopsi dari istilah bahasa Inggris lacquer yaitu bahan damar yang dihasilkan oleh sejenis serangga bernama laccifer lacca. Tumbuhan tempat bertenggernya serangga ini banyak ditemukan di Jepang, Tiongkok dan daerah pegunungan Himalaya. Orang jepang menyadapnya dari pohon tersebut sekali dalam 10 tahun. Di Sumatera Selatan pohon tersebut dikenal dengan nama pohon komalo, (Pagar Alam Post, kamis 26 April 2016).

Lukisan laker adalah karya seni lukis khas Palembang, yang memiliki keunikannya sendiri. Lukisan lak Palembang ini belum begitu banyak dikenal oleh masyarakat, karena keberadaanya juga relatif belum lama. Lukisan Laker sendiri merupakan hasil pengembangan dari seni kerajinan lak yang memang sejak lama dikenal oleh masyarakat luas. Seperti halnya seni kerajinan lak, lukisan lak pun memiliki sensitifitas yang tinggi terhadap cahaya, dengan kata lain lukisan lak ini memiliki pesona yang lebih bila mendapat sumber cahaya yang cukup atau ditempatkan di ruang yang terang.

Dari penjelasan yang telah dikemukakan dapat disimpulkan bahwa lukisan laker adalah lukisan khas Palembang yang merupakan hasil pengembangan dari seni kerajinan lak Palembang yang memiliki ciri khas tersendiri, baik teknik, proses pembuatan dan warna, seperti pada karya Muhammad Idris pelukis di sanggar Ganesha Palembang berikut ini:

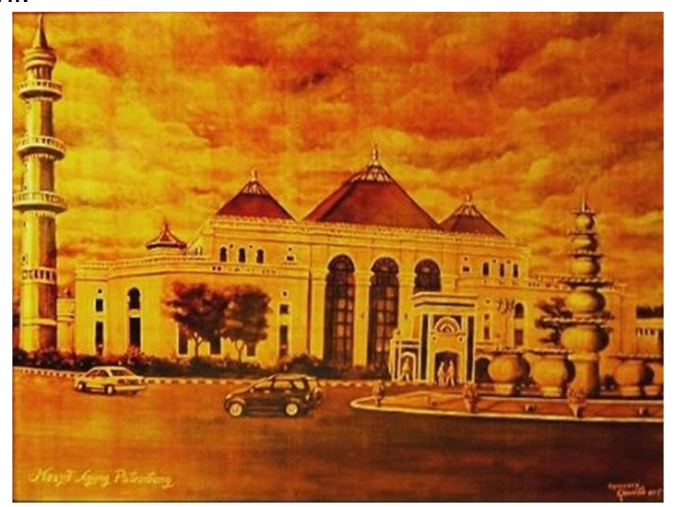

Gambar 1: Seni lukis laker "Masjid Agung

Palembang" karya Muhamad Idris, hard board $60 \times 80 \mathrm{~cm}$, koleksi galeri sanggar Ganesha Palembang,

(Dok: Suparman. foto: Mainur, 2018)

\section{Sanggar Ganesha}

Sanggar Ganesha adalah salah satu sanggar seni rupa yang terdapat di kota Palembang yang didirikan pada tahun 1978. Dengan tujuan untuk menghimpun pekerja seni atau seniman muda di Palembang. Sanggar seni rupa yang beralamat di Jl. KH Ahmad 
Dahlan nomor 74 Bukit Kecil Palembang ini dipimpin oleh Bapak Harun Rosidi Kamil yang merupakan alumni Fakultas Seni Rupa dan Desain (FSRD), Institut Teknologi Bandung. Beliau selain aktif mempunyai sanggar juga selaku ketua Himpunan Seni Rupa dari Sumatra Selatan (HSRI-SS), beliau juga adalah tokoh seni rupa atau seniman seni rupa yang juga ikut sebagai pendiri Sekolah Menengah Seni Rupa (SMSR) bersama Bapak A. Manaf dan Abdullah Saleh.

\section{B. METODE PENELITIAN}

Metode penelitian kualitatif sering disebut metode penelitian naturalistic karena penelitiannya dilakukan pada kondisi yang alamiah (natural setting); disebut juga sebagai metode etnographi, karena pada awalnya metode ini lebih banyak digunakan untuk penelitian bidang antropologi budaya; disebut metode kualitatif, karena data yang terkumpul dan analisisnya lebih bersifat kualitatif (Sugiono, 2014:37).

Penelitian kualitatif adalah penelitian yang bermaksud untuk memahami fenomena tentang apa yang dialami oleh subjek penelitian misalnya perilaku, persepsi, motivasi, tindakan dan lain-lain, secara holistic dan dengan cara deskripsi dalam bentuk kata-kata dan bahasa, pada suatu konteks khusus yang alamiah dan dengan memanfaatkan berbagai metode ilmiah (Moleong, 2014:6).

Sesuai dengan pokok permasalahan yang dikaji, penelitian ini menggunakan pendekatan kualitatif, yaitu pendekatan dengan cara melihat objek penelitian sebagai suatu sistem, dengan kata lain objek kajian dilihat sebagai satuan yang terdiri dari unsur yang saling terkait. Penelitian kualitatif lebih mengutamakan kualitas data. Oleh karena itu, teknik pengumpulan datanya banyak menggunakan wawancara yang berkesinambungan dan observasi langsung. Peneliti bermaksud menggambarkan atau menguraikan tentang alat, bahan, serta teknik pembuatan lukisan laker di sanggar Ganesha Palembang. Penelitian yang dilakukan bersifat kualitatif, artinya penelitian yang menghasilkan data deskriptif analisis yang berupa kata-kata tertulis terhadap apa yang diamati, atau dengan kata lain data yang dianalisis dan hasil analisisnya berbentuk deskriptif.

\section{HASIL PENELITIAN DAN PEMBAHASAN}

Kota Palembang adalah ibu kota Provinsi Sumatera Selatan. Palembang adalah kota terbesar kedua di Sumatera setelah Medan.

Untuk mengetahui bagaimana proses pembuatan lukisan laker yang dilakukan di sanggar Ganesha. Sanggar Ganesha pertama kali terbentuk di Bandung pada tahun 1978, anggotanya terdiri dari mahasiswa Institut Teknologi Bandung (ITB) yang berasal dari kota Palembang. Pada tahun 1980 Bapak Harun Rosidi Kamil yang merupakan salah satu pendiri dari sanggar Ganesha ini kembali ke kota kelahirannya dan mendirikan sanggar Ganesha di tempat rumah kediamannya yang beralamat di Jln. KH. Ahmad Dahlan nomor 74 Bukit Kecil Palembang.

Lokasi sanggar ini begitu strategis, terletak di pinggir jalan raya dan di tengahtengah kota dan berdekatan dengan wisata taman Kambang Iwak dan rumah dinas Wali Kota. Akan tetapi agak sedikit sulit menemukannya karena di halaman tempat lokasi tidak terdapat plank yang menunjukkan tempat lokasi sanggar Ganesha.

Melukis lak adalah kegiatan melukis yang menggunakan laker sebagai salah-satu dari media lukisnya. Laker identik dengan kuning yang menjadi pelapis hiasan dengan sapuan cat hitam, dan keemasan hingga terlihat mencolok. Banyak masyarakat Palembang menamai hiasan pewarna tersebut dengan istilah lak atau laker, walaupun nama lak lebih kental dengan istilah lemari ukir Palembang.

Dalam penelitian ini penulis mengamati proses pembuatan lukisan laker secara langsung di sanggar Ganesha yang dilakukan oleh Muhammad Idris salah seorang anggota dan seniman di sanggar Ganesha.

Alat-alat yang digunakan dalam pembuatan lukisan laker sama seperti alat yang digunakan pada alat lukis pada umumnya yaitu kuas, palet, dan pensil. Sementara gergaji dan 
amplas digunakan untuk mengolah media yang akan dilukis. Alat-alat yang digunakan yaitu:

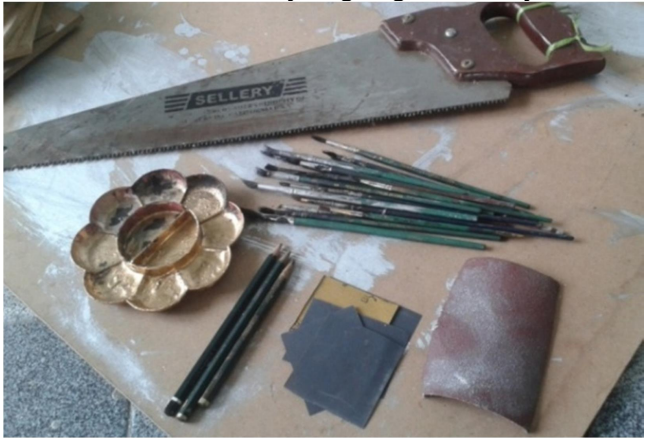

Gambar 2: Alat-alat

1. Gergaji : Berfungsi untuk memotong Hard Board / MDF atau medialukis.

2. Palet : Merupakan tempat atau wadah untuk cat warna emas.

3. Kuas :Berfungsi untuk mengaplikasikan cat atau warna dan memberi bentuk pada lukisan.

4. Pensil : Berfungsi untuk membuat sketsa awal lukisan.

5. Amplas : Berfungsi meratakan atau menghaluskan media dan lukisan.

6. Kain lap: Berfungsi untuk membersihkan kuas

Dalam teknik melukis laker akan melalui tiga proses tahapan yaitu tahap awal, tahap kedua, dan tahap akhir. Berikut adalah tahapantahapan tersebut:

1. Tahap Awal

Media yang telah disiapkan dan dipotong sesuai ukuran diberi warna dasar dengan menggunakan cat minyak yang telah dicampur dengan tinner.

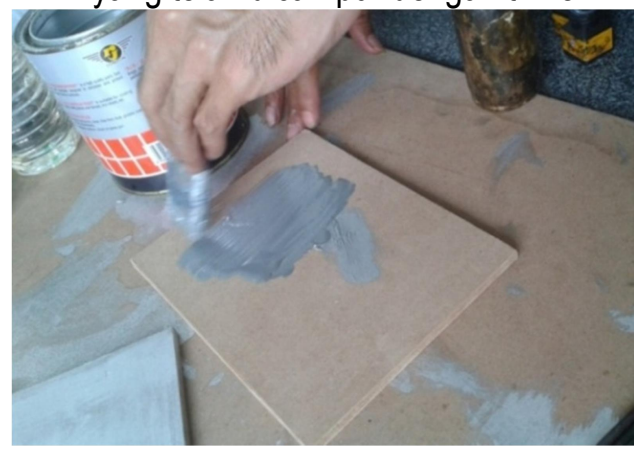

Gambar 3: Pemberian Warna Dasar

Media yang telah diberi warna dasar dan catnya telah kering lalu dibuat sketsa gambar dengan menggunakan pensil.

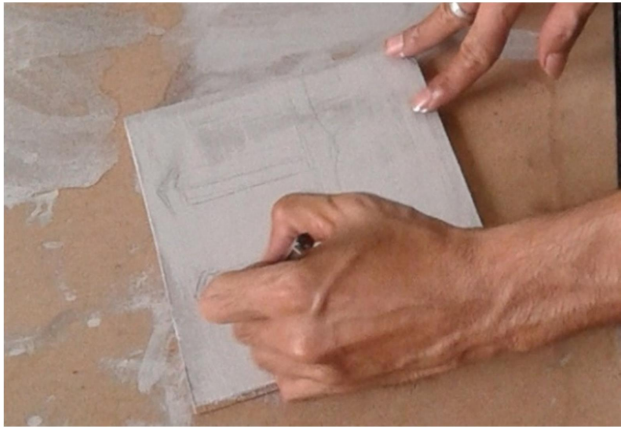

Gambar 4: Membuat Sketsa

Setelah digambar sketsa dengan menggunakan pensil lalu gambar sketsa tersebut diperjelas atau dilukis dengan cat warna hitam dari tinta cina dan cat berwarna emas dari serbuk emas (perada) yang telah dicampur pernis (kayu) menggunakan kuas.

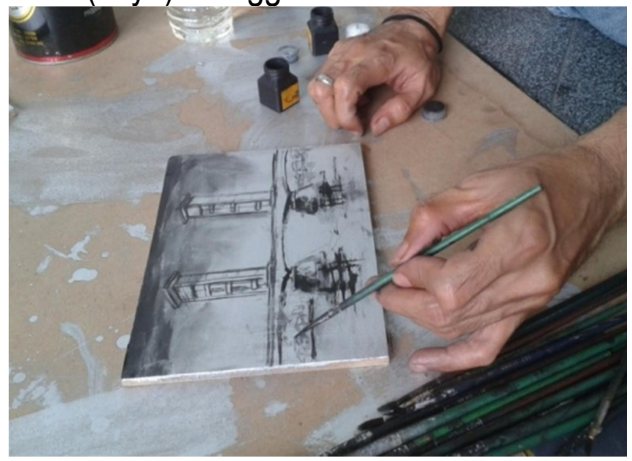

Gambar 5: Teknik awal melukis

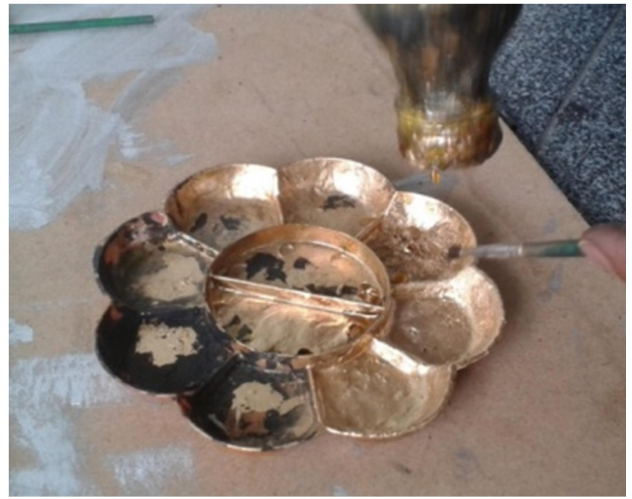

Gambar 6: Serbuk emas yang dicampur pernis 


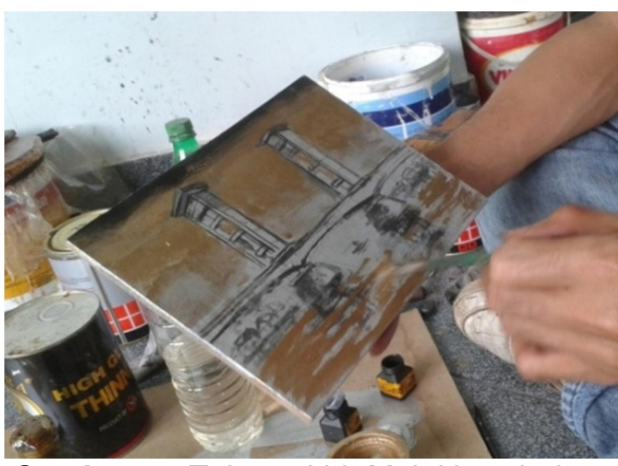

Gambar 7: Tahap akhir Melukis sebelum penjemuran

2. Tahap Kedua

Di tahap kedua setelah Media telah di lukis dengan menggunakan tinta cina dan cat emas lukisan kemudian di jemur beberapa menit, setelah dijemur beberapa menit lukisan lalu dipoles atau dilapisi dengan lacquer lalu di jemur lagi kemudian dipoles lagi lalu dijemur lagi hingga 4-5 kali pemolesan dan penjemuran hingga warnanya menjadi kecoklatan dan berkilau.

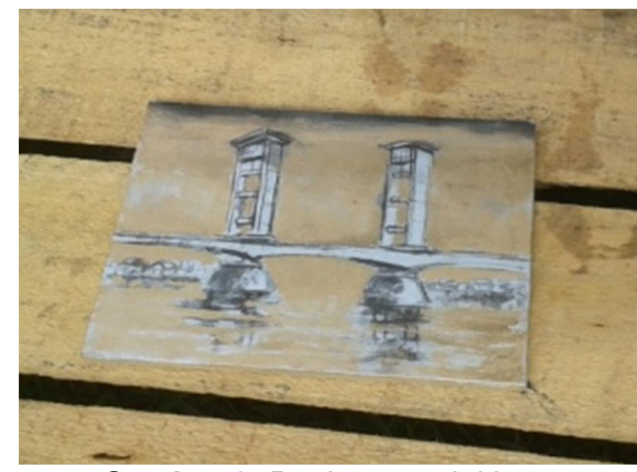

Gambar 8: Penjemuran lukisan

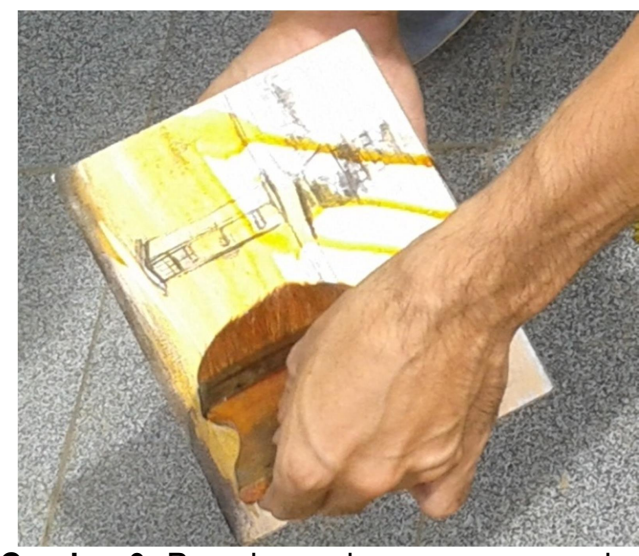

Gambar 9: Pemolesan dengan menggunakan lacquer

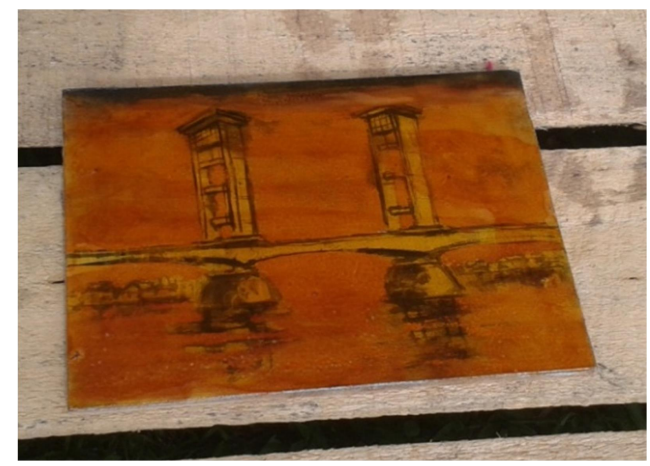

Gambar 10: Proses penjemuran lukisan yang telah dipoles 5 kali

Setelah lukisan dijemur beberapa jam dan telah kering lukisan lalu diamplas menggunakan amplas halus yang dibasahi dengan air, pengamplasan dilakukan agar permukaannya halus dan mudah dilukis, setelah rata dan halus baru kemudian dilukis lagi dengan menggunakan tinta cina dan cat emas.

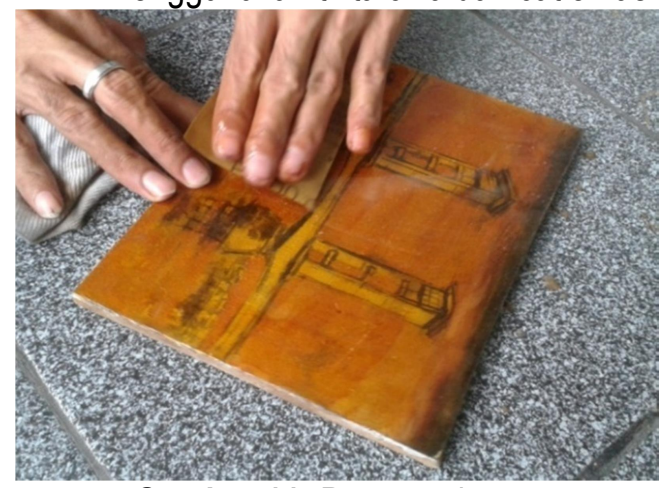

Gambar 11: Pengamplasan

\section{Tahap Ketiga}

Di tahap ketiga, media yang telah dilukis di tahap kedua kemudian di jemur lagi beberapa menit. Setelah dijemur lukisan lalu di poles lagi dengan menggunakan laker dan dijemur berulang hingga 3 kali pemolesan dan penjemuran.

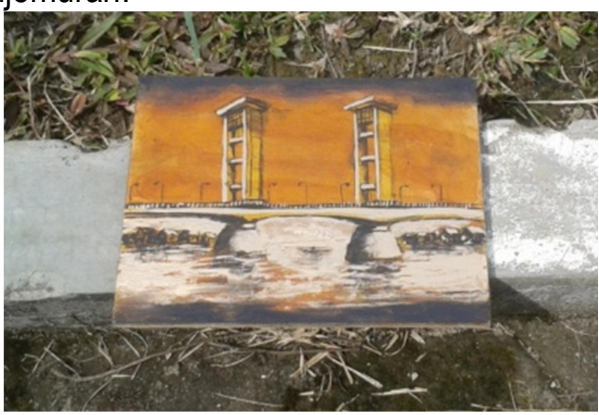

Gambar 13: Penjemuran 


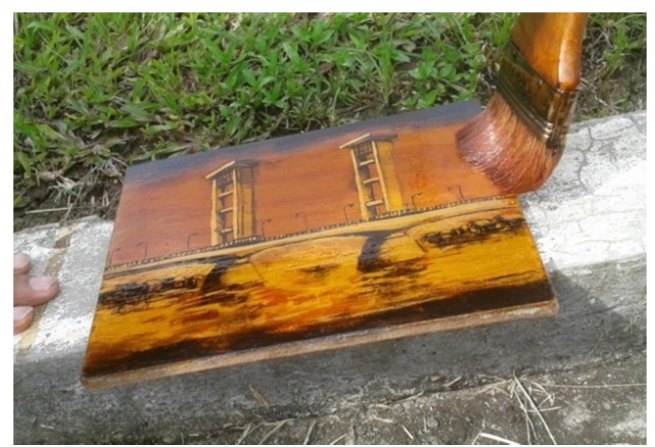

Gambar 14: Pemolesan dan penjemuran tahap ke 3

Setelah lukisan di poles menggunakan laker dan dijemur kemudian lukisan diamplas lagi menggunakan amplas halus dengan dibasahi air kemudian dijemur lagi.

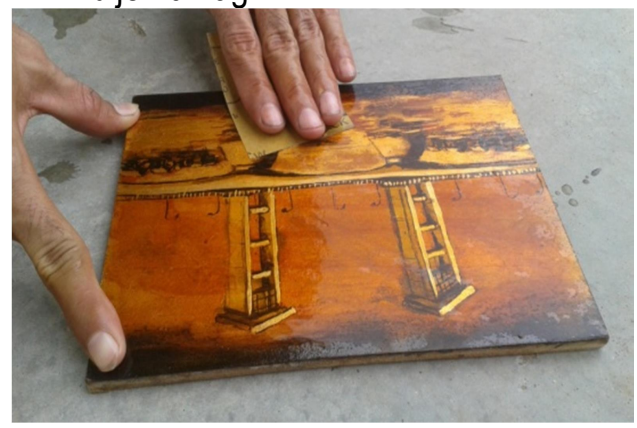

Gambar 15: Pengamplasan

Media yang telah diamplas dan dijemur lalu dilukis lagi dengan cat hitam dan emas.

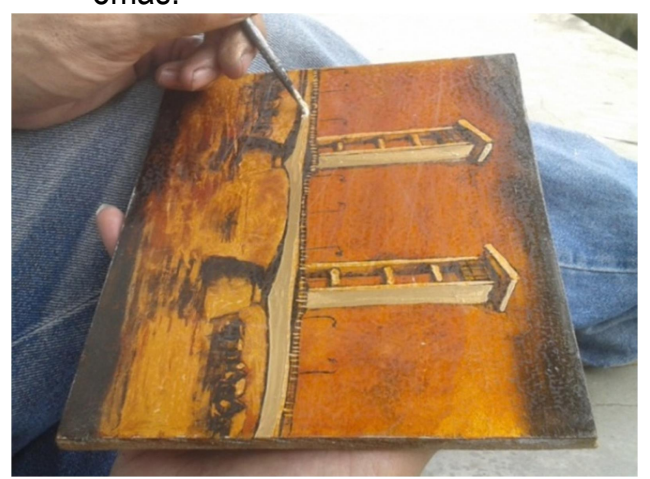

Gambar 16: Proses Melukis ditahap ke 3

4. Tahap Akhir

Tahap akhir ini merupakan tahap finishing, Media yang telah dilukis di tahap ke 3 lalu dipoles lagi menggunakan laker lalu dijemur secara berulang sebanyak 2 kali pemolesan dan penjemuran.Lukisan yang telah poles menggunakan laker dan dijemur kemudian diamplas lagi menggunakan amplas halus sambil dibasahi dengan menggunakan air agar permukaan lukisan halus. Kemudian lukisan lalu dijemur hingga kering.

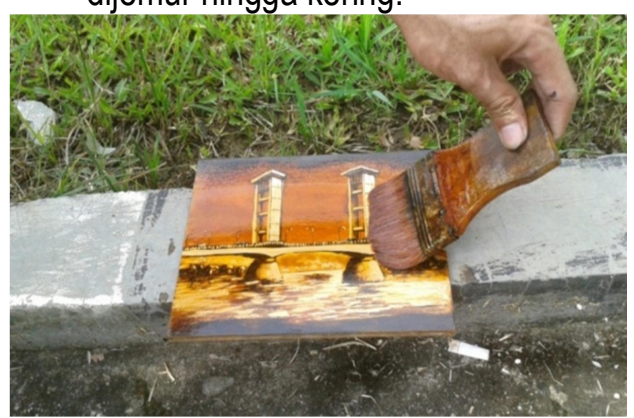

Gambar 17: Proses pemolesan laker dan penjemuran

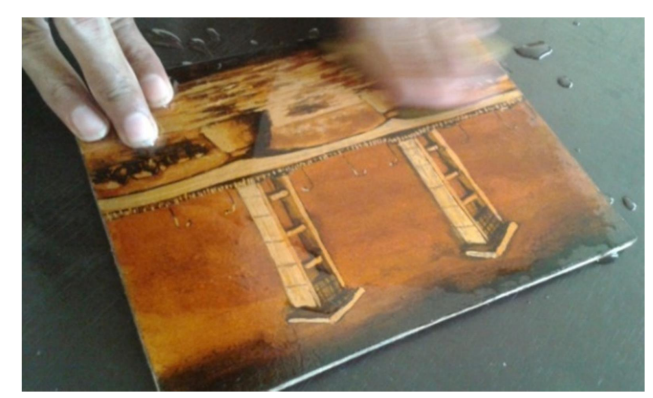

Gambar 18: Proses pengamplasan

Setelah diamplas dan dijemur hingga kering baru kemudian ke proses finishing yaitu pemolesanpernis pada lukisan dengan menggunakan kuas lalu dijemur lagi.Di proses finishing akan terlihat lukisan tampak lebih berkilau dan menandakan bahwa lukisan telah jadi atau selesai dibuat.

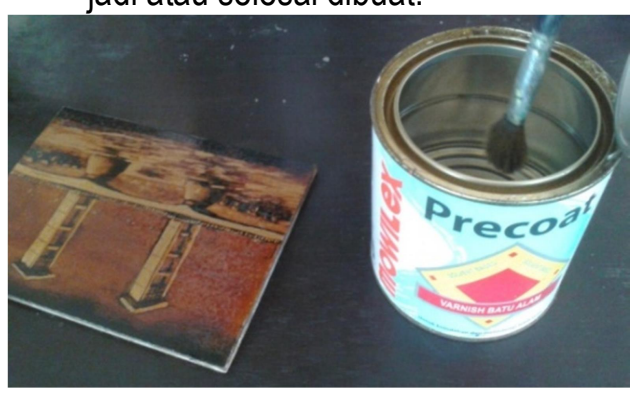

Gambar 19: Proses pemolesan pernis 


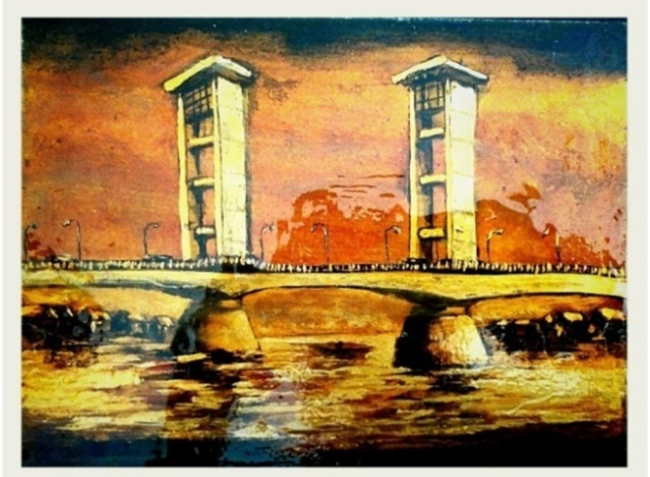

Gambar 20: Lukisan yang telah jadi

Teknik observasi yang dilakukan dalam penelitian ini bertujuan untuk mengumpulkan data dengan cara pengamatan secara langsung terhadap objek yang akan diteliti atau tempat yang menjadi pokok permasalahan yang dihadapi. Maka diperlukan pengamatan dengan caraobservasi dan melihat secara langsung terhadap karya-karya lukisan laker yang ada di galeri serta keadaan di sanggar ganesha. Dalam penelitian ini observasi dilakukan selama satu hari.

Teknik wawancara yang digunakan yaitu wawancara bebas terpimpin dan terstruktur, teknik wawancara ini bertujuan untuk memperoleh informasi sebanyak-banyaknya mengenai objek penelitian. Dalam wawancara ini narasumber yang dipilih adalah Muhammad Idris selaku seniman lukis dan anggota sanggar Ganesha.

Pengolahan data dokumentasi dilaksanakan pada saat proses pelaksanaan penelitian, dari mulai mengobservasi, proses pembuatan lukisan laker, sampai ke tahap wawancara. Adapun bentuk-bentuk dokumentasi yang digunakan oleh peneliti berupa foto pada saat proses penelitian berlangsung di lokasi penelitian yaitu di sanggar Ganesha Palembang, seperti di bawah ini:

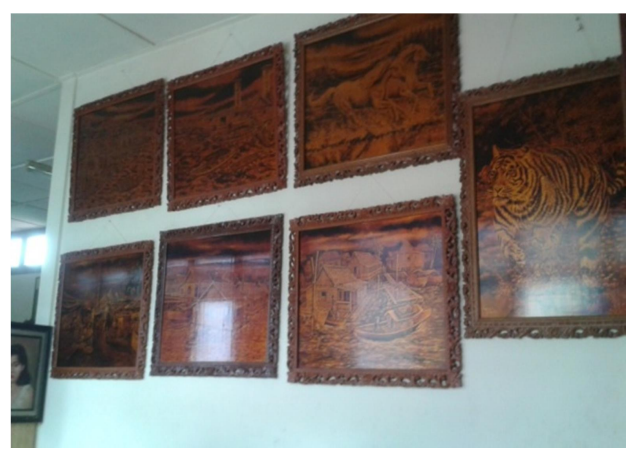

Gambar 21: Karya-karya seni lukis laker di sanggar Ganesha

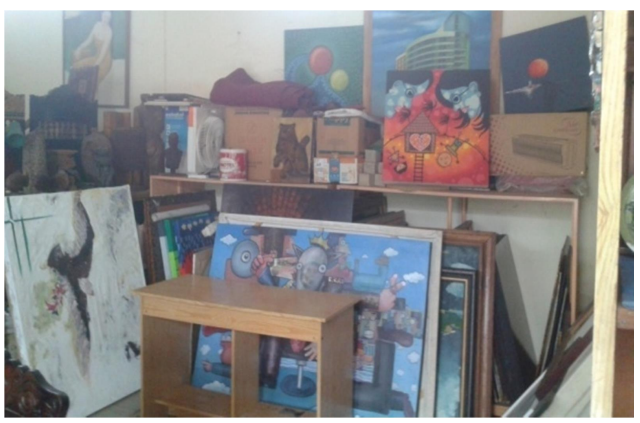

Gambar 22: Karya-karya seni lukis di sanggar Ganesha

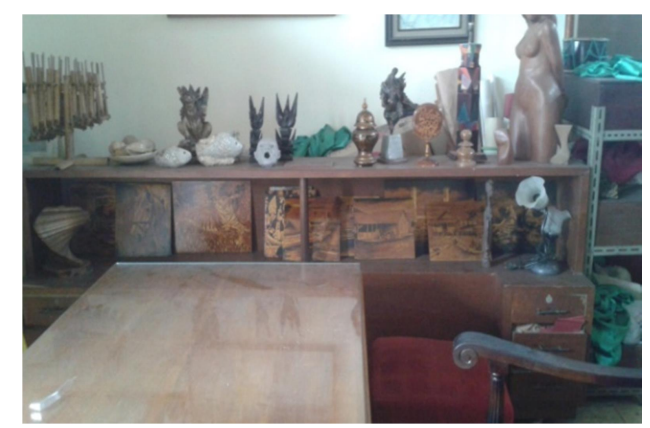

Gambar 23: Karya-karya seni 2 dimensi dan 3 dimensi di sanggar Ganesha

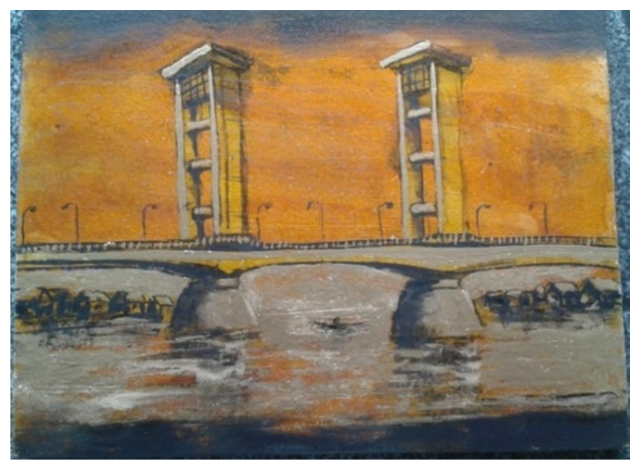

Gambar 24: Media yang telah dilukis 
Dari hasil observasi yang didapat dalam objek penelitian yaitu berupa bahan dan alat apa saja yang digunakan dalam proses pembuatan karya seni lukis laker di sanggar Ganesha Palembang. Subjek yang diteliti yaitu Muhammad Idris selaku seniman lukis dan anggota dari sanggar Ganesha Palembang yang saat ini masih aktif membuat karya seni lukis laker.

Penulis berpedoman pada lembar wawancara yang telah dibuat dan hasil yang didapat yaitu berupa jawaban-jawaban dari pimpinan atau ketua sanggar Ganesha yaitu Bapak Harun Rosidi Kamil, dan Muhammad idris selaku seniman lukis di sanggar Ganesha tersebut. Dapat disimpulkan bahwa hampir seluruh indikator yang merupakan poin dari lembar wawancara sesuai dengan yang diamati.

Dari hasil deskripsi data dokumentasi sebelumnya yang telah dilakukan oleh peneliti maka didapat seluruh dokumentasi dalam bentuk foto dari awal proses hingga akhir proses pembuatan karya seni lukis laker di sanggar Ganesha Palembang.

Penelitian ini bertujuan untuk mengetahui bagaimana proses pembuatan karya seni lukis laker di sanggar Ganesha Palembang. Dalam penelitian ini dilakukan dalam 3 hari, di hari pertama yaitu observasi untuk mengetahui tentang seni lukis laker dan sejarah serta keadaan sanggar Ganesha, di hari ke dua, yaitu pengamatan proses pembuatan lukisan laker secara langsung, dan di hari ketiga yaitu dilakukan wawancara dengan berpedoman dengan lembar wawancara yang telah dibuat. Sedangkan proses dokumentasi dilakukan dari hari pertama hinggar akhir penelitian.

Dengan kata lain selama proses penelitian berlangsung semua berjalan dengan baik walaupun masih terdapat beberapa kekurangan-kekurangan.

Dalam penelitian tentang proses pembuatan karya seni lukis laker terdapat 4 tahapan pengerjaan, yaitu tahap pertama menyiapkan bahan dan alat, tahap kedua membuat sketsa gambar, tahap ketiga mewarnai atau melukis, kemudian tahap ke empat finishing. Tahap ketiga merupakan tahap yang paling lama dalam proses pengerjaannya, karena di tahap ketiga terdapat 4 tahapan lagi dalam teknik melukis seperti yang telah di deskripsikan dalam teknik melukis pada hasil deskripsi proses pembuatan lukisan laker. Ukuran media yang besar akan memakan waktu yang cukup lama hingga satu bulan lebih. Jadi, media yang digunakan pada proses pembuatan lukisan dalam penelitian ini menggunakan media yang berukuran kecil. Sehingga penelitian ini dapat berjalan dengan baik dalam waktu yang telah ditentukan dan disesuaikan.

Seni lukis laker adalah salah satu cabang seni rupa murni dua dimensi yang menggabungkan konsep seni kria kerajinan khas Palembang dan seni lukis. Tema yang diangkat dalam lukisan laker rata-rata bangunan atau gambaran bentuk kebudayaan Palembang. Seperti Jembatan Ampera, pasar 16 ilir, Masjid Agung Palembang, Rumah Rakit, dan lain sebagainya. Artinya karya-karya lukisan laker ini rata-rata memiliki jenis lukisan atau bergenre realis atau bentuk lukisan yang objeknya mengangkat kehidupan sehari-hari atau bentuk nyata.

Bentuknya yang unik dengan paduan warna hitam, kuning emas kecoklatan yang berkilau membuat orang yang melihat lukisan laker ini seakan bernostalgia lantaran gaya lukisannya yang terlihat klasik, ditambah lagi objek yang dilukis rata-rata gambaran budaya yang ada di kota Palembang. Maka tak heran jika banyak kolektor dan para pejabat mengkoleksi seni lukis laker ini.

\section{SIMPULAN}

Adapun kesimpulan yang dapat diuraikan dari hasil penelitian mengenai proses pembuatan karya seni lukis laker di sanggar Ganesha Palembang adalah:

Lukisan laker adalah karya seni rupa murni dua dimensi yang merupakan hasil pengembangan dari seni kerajinan lak Palembang yang memiliki ciri khas tersendiri.Laker identik dengan kuning yang menjadi pelapis hiasan dengan sapuan cat hitam, dan keemasan hingga terlihat mencolok. Dari beberapa referensi, diketahui nama laker diadopsi dari istilah bahasa Inggris lacquer, yaitu bahan damar yang dihasilkan oleh sejenis serangga bernama Laccifer lacca.Tumbuhan 
tersebut merupakan tempat bertenggernya serangga dan banyak ditemukan di Jepang, Tiongkok, dan Pegunungan Himalaya.

Bahan utama yang digunakan merupakan bahan-bahan tradisional diantaranya yaitu kemalau, atau berupa butiran-butiran yang berbentuk seperti sarang semut yang dihasilkan dari pohon durian, serbuk emas atau yang biasa disebut parada. Bahan yang dijadikan media yaitu Hardboart, MDF, atau papan triplek yang permukaannya datar. Dan bahan pendukung lainnya adalah spritus, cat minyak, tinner, pernis, dan minyak tanah.

Alat yang digunakan dalam membuat lukisan laker yaitu sama halnya seperti alat melukis pada umumnya seperti kuas, palet, pensil. Sementara gergaji digunakan untuk memotong media sesuai ukuran yang diinginkan dan amplas digunakan untuk meratakan atau menghaluskan permukaan media yang akan dilukis.
Teknik dalam membuat lukisan laker memiliki 4 tahapan. Yaitu, tahapan pertama pemberian warna dasar dengan menggunakan cat minyak berwarna silver, pembuatan sketsa, dan membentuk gambar. Tahapan kedua yaitu pemolesan lacquer, penjemuran, pengamplasan, pewarnaan. Tahap ketiga yaitu pemolesan lacquer, penjemuran, pengamplasan, pewarnaan. Dan tahap ke empat pemolesan lacquer, penjemuran, dan finishing pemolesan dengan menggunakan pernis.

Lukisan laker memiliki bentuk yang unik dengan paduan warna hitam, kuning emas kecoklatan yang berkilau membuat orang yang melihat lukisan laker ini seakan bernostalgia lantaran gaya lukisannya yang terlihat klasik, ditambah lagi objek yang dilukis rata-rata bentuk atau gambaran budaya yang ada di kota Palembang.

\section{Daftar Pustaka}

Dharsono. 2004. Seni Rupa Modern. Bandung: Rekayasa Sains

, 2007. Keritik Seni. Bandung: Rekayasa Sains

Moleong, J. Lexy. 2014. Metodologi Penelitian Kualitatif. Bandung: PT. Remaja Rosdakarya.

Sugiyono. 2014. Metode Penelitian Manajemen. Bandung:Alfabeta.

Sumardjo, Jacob. 2000. Filsafat Seni. Bandung: Institut Teknologi Bandung

Yuliastuti, Rima. 2009. Apresiasi karya seni tari. Tanggerang: PT.Pantja simpati. 